\title{
Occurrence of gastrointestinal parasites in goats from the Western Santa Catarina, Brazil
}

\author{
Ocorrência de parasitas gastrintestinais em caprinos na região Oeste de Santa Catarina, Brasil
}

Willian Mauricio Radavelli ${ }^{1}$; Rafael Pazinato ${ }^{1}$; Vanderlei Klauck ${ }^{1}$; Andréia Volpato ${ }^{1}$; Alexandre Balzan ${ }^{1}$; Julia Rossett ${ }^{1}$; Chrystian Jassanã Cazarotto ${ }^{1}$; Leandro Sâmia Lopes ${ }^{1}$; Julcemar Dias Kessler'; Diego Córdova Cucco'; Alexandre Alberto Tonin²; Aleksandro Schafer Da Silva ${ }^{1 *}$

${ }^{1}$ Department of Animal Science, Universidade do Estado de Santa Catarina - UDESC, Chapecó, SC, Brazil

${ }^{2}$ Department of Microbiology and Parasitology, Universidade Federal de Santa Maria - UFSM, Santa Maria, RS, Brazil

Received August 18, 2013

Accepted January 21, 2014

\begin{abstract}
This study aims to investigate the occurrence of gastrointestinal parasites in goats from the Western Santa Catarina, Brazil. Twenty four farms were analyzed in 17 different municipalities. Animals $(n=217)$ from different production purposes (milk and meat) and age were randomly chosen. Fecal samples were collected from the rectum stored in plastic bottles and transported to the laboratory in portable coolers at $10^{\circ} \mathrm{C}$. The technique of centrifugal flotation with saturated sugar solution was carried out in order to investigate the presence of eggs, cysts, and oocysts of gastrointestinal parasites. In $88.9 \%$ of the investigated animals, it was observed that the presence of nematode eggs which belongs to the Strongylida order, after cultivation and larvae identification were identified as Haemonchus spp., Trichostrongylus spp., Teladorsagia spp., Cooperia spp., and Oesophagostomum spp. Eggs of Thysanosoma, Trichuris, Moniezia, and Neoascaris genus were also observed. Additionally, the presence of oocysts of Eimeria spp. and Cryptosporidium spp. as well as cysts of Giardia spp., and Entamoeba spp. were verified. In all the farms evaluated, the animals showed a single or mixed infection, with the highest occurrence of helminths belonging to the Haemonchus and Trichostrongylus genus, as well as the protozoan Eimeria.
\end{abstract}

Keywords: Goats, endoparasites, Strongylida, Eimeria, protozoa.

\section{Resumo}

O presente estudo objetivou investigar a ocorrência de parasitas gastrointestinais que infectam caprinos na região Oeste de Santa Catarina, Brasil. Foram analisadas 24 propriedades localizadas em 17 municípios, totalizando 217 caprinos. Os animais de diferentes categorias de produção (leite ou carne) e idade foram escolhidos aleatoriamente. A coleta das fezes foi realizada diretamente da ampola retal dos animais, armazenadas em frascos plásticos e transportadas para o laboratório em caixas térmicas a $10^{\circ} \mathrm{C}$. A técnica de centrífugo-flutuação com solução saturada de açúcar foi utilizada para pesquisar a presença de ovos, cistos e oocistos de parasitos. Em $88,9 \%$ dos animais analisados foi verificada a presença de ovos de nematóides da ordem Strongylida e, após cultivo, foram identificadas larvas de Haemonchus spp., Trichostrongylus spp., Teladorsagia spp., Cooperia spp. e Oesophagostomum spp. Foram identificados também ovos de parasitos dos gêneros Thysanosoma, Trichuris, Moniezia e Neoascaris. A presença de oocistos de Eimeria spp. e Cryptosporidium spp., e cistos de Giardia spp., e Entamoeba spp. foram observadas. Em todas as propriedades avaliadas, os animais apresentavam infecçóes simples ou mistas, sendo a maior ocorrência de helmintos do gênero Haemonchus e Trichostrongylus, assim como pelo protozoário Eimeria.

Palavras-chave: Caprinos, endoparasitas, Strongylida, Eimeria, protozoários.

\footnotetext{
${ }^{*}$ Corresponding author: Aleksandro Schafer Da Silva

Departamento de Zootecnia, Universidade do Estado de Santa Catarina -

UDESC, R. Beloni Trombeta Zanini, 680E, Santo Antônio, CEP 89815-630,

Chapecó, SC, Brasil

e-mail: aleksandro.silva@udesc.br
} 
Usually goats are bred for meat, milk and hide. In the South and Southeast of Brazil, the goat production is mainly for milk and dairy products. According to IBGE (2010), Santa Catarina herd is of approximately 58 thousand animals, of which nearly $50 \%$ are located in the West part of the State.

Health problems in goat may lead to reduction in production, and among these problems gastrointestinal nematodes and the coccidian infections stand out, which may limit production of these small ruminants. The main gastrointestinal nematodes observed in goat are: Haemonchus contortus, Trichostrongylus spp., Cooperia spp., Oesophagostomum spp., Trichuris spp., and Strongyloides papilosus (VIEIRA, 2005), in addition to the coccidian Eimeria spp. These parasites are the main cause of significant economic losses, due to high mortality and reduction of growth performance of infected animals (COSTA JÚNIOR et al., 2005). However, these economic losses depend on several factors such as climatic conditions, production system, nutritional and developmental status of the animal, as well as its physiological status (MATTOS; CASTRO, 2002).

Besides eimeriosis and gastrointestinal nematodes, Giardia spp. and Cryptosporidium spp. can cause health problems in small ruminants. Although these protozoa contribute to production losses, they affect goats and sheep in a lower degree (BASTIANI et al., 2012). Giardiasis has been associated with diarrhea, decreased weight gain, anorexia, and lethargy in young animals (KIORPES et al., 1987; BASTIANI et al., 2012). Due to the major health problems caused by gastrointestinal infections of parasites in small ruminants in several places throughout the world, this study aimed at investigating and identifying the most prevalent gastrointestinal protozoa and helminths in herds of goats from the Western Santa Catarina (SC), Brazil.

In the present study, 217 goats were evaluated between October 2012 and March 2013. This number was reached based on a geographical study that selected 24 farms in municipalities with a greater number of goats in the west of SC, Brazil. Animals of different productive fitness (milk or meat) included in the study were randomly chosen represented mainly by adult (201 goats). For sampling, the animals were restrained manually, while feces were collected directly from the rectum. The samples were stored in plastic bottles and maintained in coolers $\left(10^{\circ} \mathrm{C}\right)$ until laboratorial processing. It was performed by the centrifugal flotation technique with supersaturated sugar solution, allowing the microscopic search of eggs, cysts, and oocysts of parasites through microscopy (10 to $40 \mathrm{x}$ ). Identification of parasites from the Strongylida order was carried out by larvae culture according to the methodology described by Roberts and O'Sullivan (1950). A pooled sample was used to identify the protozoan oocysts in each farm and samples were incubated at $25^{\circ} \mathrm{C}$ and $75 \% \mathrm{RH}$, to allow oocyst sporulation and genus identification. A questionnaire was administered to farmers to obtain information with regards to breed, sex, age, diet, water source, productive purpose (meat or milk) and the presence of diarrhea in relation to parasitism. This data was analyzed using Fisher's Exact Test and $\chi^{2}$.

All the 217 goats were parasitized by helminthes and/or protozoa. It was possible to visualize eggs of the Strongylida order, eggs of Thysanosoma, Trichuris, Moniezia, and Neoascaris. Oocysts of Eimeria and Cryptosporidium as well as cysts of Entamoeba and Giardia were also detected (Table 1). In order to confirm the presence of Cryptosporidium spp., oocysts were stained using Kinyoun modified method (AMATO NETO et al., 1996). All samples positive for Cryptosporidium spp in the centrifugal flotation technique were also positive according to the Kinyoun method.

Moreover, it stands out the occurrence of nematodes of the Strongylida order in 193 (88.94\%) of the samples. After the larvae cultivation of the samples in which eggs of the Strongylida order were observed, it was possible to identify Haemonchus and Trichostrongylus as the most prevalent helminths, present in $81.1 \%$ and $77.4 \%$ of animals, respectively. Teladorsagia was present in $62.6 \%$ of the goat, while Cooperia and Oesophagostomum were the parasites found in the lower rates, representing $15.5 \%$ and $4.1 \%$, respectively. In addition, oocystis of Eimeria and Cryptosporidium were observed in $68.2 \%$ and $40.5 \%$ of the samples, respectively (Table 1). Also, Giardia spp. was found in $22.6 \%$ of the samples, along with Entamoeba (1.84\%) in smaller proportion (Table 1).

Our results showed that gastrointestinal parasites were found in all the farms assessed in this study, differing in type of infection (single or mixed) and genus of parasites. Similar results were reported by Brito et al. (2009) in sheep and goats raised in the microregion of Alto Mearim and Grajaú (Maranhão State, Northeast of Brazil), when $91.66 \%$ and $69.79 \%$ tested positive to helminths and coccidia respectively. Martins-Filho and Menezes (2001) and Pimentel Neto et al. (1999) detected the simultaneous presence of helminthes and coccidian in herds of the states of Paraíba and Rio de Janeiro, respectively. Both studies suggested the possibility of damage on these herds due to parasitism, especially in body weight.

Eimeria spp. was present in $68.2 \%$ of the samples, similar to those results showed by Hassum and Menezes (2005), which observed a parasitism rate of $77.63 \%$ in young and adult goats. Brito et al. (2009) reported indexes of $69.79 \%$ of goats and sheep with Eimeria spp. More striking findings were reported by Freitas et al. (2005) in a study conducted in São José do Rio Preto, São Paulo state, where 100\% of the animals examined had one or more species of the genera Eimeria. In

Table 1. Gastrointestinal helminthes and protozoan of goats $(n=217)$ from the Western Santa Catarina, Brazil.

\begin{tabular}{lcc}
\hline \multicolumn{1}{c}{ Parasites } & $\begin{array}{c}\text { Number of } \\
\text { positive samples }\end{array}$ & $\begin{array}{c}\text { Percentage of } \\
\text { positive samples (\%) }\end{array}$ \\
\hline Thysanosoma spp & 23 & 10.6 \\
Trichuris spp & 20 & 9.2 \\
Neoascaris spp & 16 & 7.4 \\
Moniezia spp & 05 & 2.3 \\
& & \\
Haemonchus spp & 176 & 81.1 \\
Trichostrongylus spp & 168 & 77.4 \\
Teladorsagia spp & 136 & 62.6 \\
Cooperia spp & 33 & 15.2 \\
Oesophagostomum spp & 09 & 4.1 \\
& & \\
Eimeria spp & 148 & 68.2 \\
Cryptosporidium spp & 88 & 40.5 \\
Giardia spp & 49 & 22.6 \\
Entamoeba spp & 04 & 1.8 \\
\hline
\end{tabular}


most cases this coccidian causes asymptomatic disease, but may cause losses due to poor feed conversion. Therefore, control programs to this parasite should be enforced.

Studies on goats performed in Paraíba state identified Oesophagostomum spp. in $46 \%$ of the samples, Cooperia spp. in $30 \%$, Haemonchus spp in 10\%, Trichostrongylus spp. in 12\% and Bunostomum spp. in 2\% of the animals (MARTINS-FILHO; MENEZES, 2001). However, different results were observed by Costa and Vieira (1984), who showed that over $80 \%$ of the parasitic load of goats was by $H$. contortus, similar to the findings reported here. Brito et al. (2009) found a ratio to Haemonchus spp. (35.41\%), Trichostrongylus spp. (27.29\%), Cooperia spp. (23.61\%), Oesophagostomum spp. (8.93\%) and Strongyloides spp. (4.75\%). It is noteworthy that in the present study the same parasites were identified, with the genus Trichostrongylus and Haemonchus being more prevalent in herds from the west of Santa Catarina state. Besides, the large number of positive samples for Eimeria oocysts and Trichostrongylidae family eggs, the goats tested were also positive for Cryptosporidium, Giardia, Entamoeba, Thysanossoma, Trichuris, Neoscaris, and Moniezia.

Furthermore, within the helminthes class, the parasites belonging to the Strongylida order were more prevalent, as already mentioned. However other helminthes were observed in the stool samples of goats, such as Thysanosoma, Trichuris, Neoscaris, and Moniezia. The occurrence of Trichuris spp. in sheep and goats was already reported in Bahia State (BAVIA et al., 1982). Another study conducted by Martins-Filho and Menezes (2001) with goats in the Paraíba state found that $7.4 \%$ of the animals were positive for the genus Trichuris and $11.84 \%$ for Moniezia, consisting in a similar result of this study current.

According to researchers, Cryptosporidium spp. can cause outbreaks of diarrhea with mortality, especially in young animals (VIEIRA et al., 1999). Therefore, the disease may lead to severe economic losses, mainly as a result of the delay in the growth and development of these animals, since their damaged intestines have lower rate of nutrient absorption. A study carried out in Ceará State (Northeast of Brazil), showed that $87.5 \%$ of the properties analyzed were positive for gastrointestinal parasites, and of these, nearly $100 \%$ of the goats were affected by Cryptosporidium spp. (VIEIRA et al., 1999).

The presence of Giardia in goats is rarely reported, but this flagellate was recently associated with sheep mortality in Southern Brazil (BASTIANI et al., 2012). Since Giardia spp. was also found in this study, it is possible to conclude that this protozoan may represent a risk to these specific herds, or for goats in general. Bomfim et al. (2004) have reported one of the first cases of giardiasis in goats in Brazil, where the presence of Giardia was observed in $33.3 \%$ of the properties surveyed in the state of Rio de Janeiro. In Brazil, reports of Entamoeba spp. in goats were unknown. However, these parasites have been described recently in goats in Tanzania (MHOMA et al., 2011).

This study observed that most of the properties (91.6\%) raised goats for their own consumption, being probably the main reason for the lack of parasitic treatment with anthelmintics. The occurrence of goat mortality in some herds was reported by owners. Therefore, there is a need to encourage producers to engage in a program of parasite control. No correlation between breed, sex, age, diet, water source, rearing purpose (meat or milk) nor between presence of diarrhea and parasitism/parasites was observed $(\mathrm{P}>0.05)$. Based on the results, we can conclude that gastrointestinal parasitic diseases are common and prevalent in goats from the Western Santa Catarina, Brazil.

\section{Ethical Approval}

Experimental protocol was approved by the Animal Welfare Committee of Universidade do Estado de Santa Catarina (UDESC), under number 1.15 .13 .

\section{References}

Amato Neto V, Braz LMA, Pietro AOD, Módolo JR. Pesquisa de oocistos de Criptosporidium sp em fezes: comparação entre os métodos de Kinyoun modificado e de Heine. Rev Soc Bras Med Trop 1996; 29(6): 575-578. PMid:9011883. http://dx.doi.org/10.1590/S0037-86821996000600008

Bastiani FT, Da Silva AS, Dück MRK, Tonin AA, Monteiro SG. Outbreak of eimeriosis and giardiasis associated to mortality of lambs in southern Brazil. Comp Clin Pathol 2012; 21(3): 371-373. http://dx.doi. org/10.1007/s00580-012-1467-9

Bavia ME, Caldas EM, Fiterman IR. Distribuição da frequência de helmintos e protozoários em ovinos e caprinos das regióes de Quinjibe, Euclides da Cunha e Monte Santo-Bahia. Arq Esc Med Vet 1982; 7(1): 121-130.

Bomfim TCB, Huber F, Gomes RS, Alves LL. Natural infection for Giardia in dairy goats in the mountain region of the State of Rio de Janeiro. Rev Bras Parasitol Vet 2004; 13(3): 89-95.

Brito DRB, Santos ACG, Teixeira WC, Guerra RMSNC. Parasitos gastrintestinais em caprinos e ovinos da microrregião do alto Mearim e Grajaú, no estado do Maranhão, Brasil. Ciênc Anim Bras 2009; 10(3): 967-974.

Costa Júnior GS, Mendonça IL, Campelo JEG, Cavalcante RR, Dantas Filho LA, Nascimento IMR, et al. Efeito de vermifugação estratégica, com princípio ativo à base de ivermectina na incidência de parasitos gastrintestinais no rebanho caprino da UFPI. Ciênc Anim Bras 2005; 6(4): 279-286.

Costa CAF, Vieira LS. Controle de nematódeos gastrintestinais de caprinos e ovinos do estado do Ceará. Sobral: Embrapa-CNPC, 1984. 6 p. (EMBRAPA - CNPC. Comunicado Técnico, n. 13).

Freitas FLC, Almeida KS, Nascimento AA, Machado CR, Veschi JLA, Machado RZ. Espécies do gênero Eimeria Schneider, 1875 (Apicomplexa: Eimeriidae) em caprinos leiteiros mantidos em sistema intensivo na região de São José do Rio Preto, estado de São Paulo, Brasil. Rev Bras Parasitol Vet 2005; 14(1): 7-10. PMid:16153337.

Hassum IC, Menezes RCAA. Infecção natural por espécies do gênero Eimeria em pequenos ruminantes criados em dois municípios do estado do Rio de Janeiro. Rev Bras Parasitol Vet 2005; 14(3): 95-100. PMid:16229752.

Instituto Brasileiro de Geografia e Estatística - IBGE. Banco de Dados Agregados: Censo Agropecuário de 2010. [online]. 2010. [cited 2013 Mar]. Available from: http://www.sidra.ibge.gov.br/bda/tabela/protabl. asp? $=73 \& z=t \& o=1 \& \mathrm{i}=\mathrm{P}$. 
Kiorpes AL, Kirkpatrick CE, Bowman DD. Isolation of Giardia from llama and from sheep. Can J Vet Res 1987; 51(2): 277-280. PMid:3607656 PMCid:PMC1255317.

Martins-Filho E, Menezes RCAA. Parasitos gastrintestinais em caprinos (Capra hircus) de uma criação extensiva na microrregião de Curimataú, estado da Paraíba, Brasil. Rev Bras Parasitol Vet 2001; 10(1): 41-44.

Mattos MJT, Castro ES. Utilização de anti-helmínticos no controle de verminose caprina no Estado do Rio Grande do Sul. Hore Vet 2002; 22(130): 52-54.

Mhoma JRL, Kanyari PWN, Kagira JM. The prevalence of gastrointestinal parasites in goats in urban and peri-urban areas of Mwanza City, Tanzania. Sci Parasitol 2011; 12(4): 191-196.
Roberts FHS, O'Sullivan JP. Methods for egg counts and larval cultures for strongyles infesting the gastrointestinal tract of cattle. Aust J Agric Res 1950; 1(1): 99-102. http://dx.doi.org/10.1071/AR9500099

Pimentel Neto M, Amaral BMPM, Brito MF, Fonseca AH. Parada de crescimento do ciclo evolutivo de Oesophagostomum columbianum (Curtice, 1890) em caprinos na Baixada Fluminense, RJ. Rev Bras Med Vet 1999; 21(4): 165-170.

Vieira LS, Cavalcante ACR, Ximenes LJF, Silva MBO. Prevalência de Cryptosporidium em rebanhos caprinos no estado do Ceará. Sobral: Embrapa Caprinos; 1999. v. 25, p. 2.

Vieira LS. Importância das endoparasitoses gastrintestinais nas explorações de caprinos e ovinos. [online]. 2005. [cited $2013 \mathrm{abr}$ ]. Available from: www. ainfo.cnptia.embrapa.br/.../1/AAC-Importancia-das-endoparasitoses.pdf. 